\title{
Political Advertising in the Crossroad of Political Pragmatism and Political Ideology
}

\section{Angelos Kissas, London School of Economics and Political Science, UK}

\begin{abstract}
The study of political advertising so far could be an exemplar of the schism that permeates the whole study of political communication nowadays; the schism between the politics of pragmatism and the politics of ideology. This paper comes to counter-argue that the study of political advertising can become an exemplar of the reconciliation of these two different areas of concern in so far as we do justice to the ontological status of discourse in political communication. This means that we should not take discourse to be a derivative of electoral design, as the legacy of modernization has taught us, but to be the primary locus where all strategies of political communication are meaningfully articulated. It is not, however, the articulation on the basis of political philosophy (ideology in liberal political theory) and for the reproduction of the social order (ideology in critical cultural studies) that grasp the ideological potential of contemporary, aestheticized and managerialized, political communication. It is rather, as I will argue, drawing on post-structuralist discourse theory, the re-contextualization of symbolisms from the past, interwoven with the precarious institutional interests and asymmetries of the present, which lies at the heart of the ideological potential of political advertising. It is, therefore, a discourse-based analytics of ads that we need so as to grasp the conditions of possibility for this potential.
\end{abstract}




\section{Introduction}

Televised political advertising has a history of more than fifty years in political communication and, so far, has massively attracted empirical research, primarily in terms of its efficacy in conveying messages to the electorate and in causing certain effects on political behaviour, attitudes and knowledge. Presidential spots in the US, for instance, have been found to constitute an even more successful source of issue learning about candidates and parties than television news coverage or televised debates (see Kaid et al, 2007, Kaid, Fernandes and Painter, 2011). Political ads have been, repeatedly, argued (rather ambiguously though) to have direct effects on voting, either by changing or by reinforcing electoral preferences, and more importantly, indirect and much more pervasive effects on the perceptions of the political process in general, especially on the merits by which candidates are judged (e.g. name recognition, stances on issues, image attributes, etc.) (Ansolabehere and Iyengar, 1995, Cwalina, Falkowski and Kaid, 2000, Kahn and Geer, 1994, Kaid and Sanders, 1978, Kaid, Chanslor and Hovind, 1992, Atkin and Heald, 1976, Kaid, 2002). The quantitative-ridden character (experiments, surveys, content analysis) of this great deal of empirical research is more interested, however, in the establishment of epiphenomenal associations between the generic aspects of ads and the observed shifting or unchanging trends (of opinion, behaviour, etc.) in the electorate rather than in the in-depth and systematic analysis of genres (Scammell and Langer, 2006), especially, in terms of the discursive and, potentially, ideological features the latter may carry with them.

Of course, someone may, reasonably, ask: is it possible and of any practical value to learn about such things as ideology through TV - and electronically mediated in general - ads the major role of which is just to foster party electability by all means and at any cost? As Manuel Castells has posed it: "'regardless of ideology and rhetoric in political discourse, only one thing matters for political parties and candidates in campaigning - winning. Everything else is a derivative" (2009, 228). As I wish to argue, however, behind this aphoristic approach to political pragmatism, lies a, widely shared, speculative account, crucially influenced by modernization theories, which, in fact, takes modern political communication to amount to a managerial activity that extensively conscripts aesthetic and emotional garnitures rather than ideologically bounded discourse so to re-attract disaffected voters from a wide range of socio-cultural backgrounds (Swanson and Mancini, 1996, Blumler and Gurevitch, 1995). It is necessary, therefore, before proceeding with any conceptual and analytical particularities in the study of ads, which will allow us to address the ideological potential of the latter, to critically revisit this popular interpretation of political pragmatism.

The loosely called modernization thesis cannot be, actually, attributed to any specific writer but it is rather broadly re-constructible through the works of several thinkers, such as Dahl (1971), Luhmann (1975), Giddens (1990), Beck (1992) and others. What binds these, temporally distanced and, sometimes, epistemologically incongruent, accounts together is their common finding that the transition from pre-modern, feudal societies to the modern, industrial to the late-modern, post-industrial ones is a process of incessant secularization, rationalization and managerialisation (see Thompson, 1990). For what I am interested in this paper, modernization thesis claims that the twentieth century, and more particularly the postwar period, signals the gradual decline of the highly divisive 'grand narratives' of liberalism, conservatism, socialism and communism as the major enclaves of political identification and mobilization. Political parties from the Right and Left considerably moved towards the center by agreeing with each other on fundamental issues about the structural arrangement of government; what has been loosely called 'welfare consensus' (or later, after the collapse of communist regimes, what could be referred as 'neoliberal consensus') (Blumler and Gurevitch, 1995, Swanson and Mancini, 1996, Hallin and Mancini, 2004, 
Dahlgren and Gurevitch, 2005). In a nutshell, political process has been 'disenchanted' by collapsing from the imaginary of passionate and zealous combat among well-established, rigid and coherent belief systems (politics of ideology) to the real experience of a complex bureaucratic and managerial activity (politics of pragmatism).

As I wish to argue, modernization thesis is crucially underpinned by an evolutionist interpretation of the development of modern societies which overemphasizes both the fanatic polarity of the past and the rationalist moderation of the present, without considering potential continuities and resurgent dynamics. Among with the continuities which modernization has underestimated is the recent re-polarization and re-radicalization of the political landscape as a result of the resurgence of radical Right (e.g. neo-fascist parties, see the case of Golden Down in Greece or ultra-nationalist parties, such as the National Front in France), radical Left (e.g. neo-populist parties, such as the Podemos in Spain and the UKIP in Britain) and religious neo-fundamentalisms (e.g. the Islamic State). Consequently, even if political pragmatism is immersed in the managerial demands of political communication, the latter cannot be said to be completely disassociated from the historical debates around political organization and mobilization. The question is how exactly these benchmarks of the past are inserted into and realigned with the vehement flow of political competition and institutional destabilization of the present and with what consequences for political communication.

As several works, directly or indirectly concerned with the study of political ideology in modern politics and society, from political science (see Brock et al, 2005) to cultural studies (see Hall, 1982) to discourse theory (see Laclau and Mouffe, 1985) and analysis (see Chouliaraki and Fairclough, 1999), have pointed out, history penetrates political pragmatism primarily through language (discourse), what, later on, I will refer as intertextuality and interdiscursivity. As I will show in the next part of this paper, the relevant paradigms from both political theory/science and cultural studies try to do justice to the quintessential role of ideology in the politics of pragmatism by relating discourse to the effective exercise of power. They do so, however, in an essentialist/consensual (rational attainment of political consensus through discursive adherence on coherent philosophical currents) and a totalizing (reproduction of a dominant order though discursive dissimulation and normalization) way respectively. As I will try to argue, drawing on post-structuralist discourse theory, it is the multi-accentually power-imbricated discursive practice of re-contextualization of symbolisms from the past, and not the consensus-oriented or domination-sustaining discursive coherence and rationality, which constitutes the par excellence ideological work of the otherwise managerially-driven political communication. Taking the example of (electronic) political advertising, in the last part of this paper, I shall focus on the analytics of practices of political communication as the only means via which we can illustrate the ideological potential of the latter. As I will try to show, we need to carefully examine the generic aspects of ads so as to understand how the latter insert (re-contextualize) history, in the forms of symbolisms, into the alleged ephemerality of media politics and how the discursive formations that derive from this re-contextualization seek to reinforce the relational position of political parties in the broader political field. 


\section{The Discursive Rearticulation of Pragmatism and Ideology in Political Science, Critical Theory and Post-Structuralist Discourse Theory}

\section{Ideology as the Philosophically-grounded Discourse that serves the establishment of Political Consensus}

Quite a lot of studies from within political science have grappled with the conceptual bifurcations and the place and role of ideology in political practice (Roucek, 1944, Mullins, 1972, Seliger, 1976, Hamilton, 1987, Lewins, 1989, Foley, 1994, Hoffman and Graham, 2006, Heywood, 2003, Freeden, 2003). The 'least common denominator of these studies' could be said to be the following: an ideology is, broadly, a belief system that organizes political though and cements political practice, by justifying and legitimizing particular policy frames, on the basis of some common, historically consolidated, values. This ordering capacity of ideology needs to be credited to the rhetorical work of political language, Brock et al (2005) argue. Taking as their point of departure Burke's understanding of language as communicative act, Brock et al echo other scholars from outside political science, such as Halliday (1994) and Fairclough (2003), in focusing on the specific functions or aspects of language that allow the meaningful articulation and, thereby, realization of a specific political act. In broad terms, language orders political practice by articulating a specific understanding of the situation in which we need to act - a definition of the reality -, by identifying specific subjects as a collectivity that share goals and pursuits - identity-making - and by charting specific forms of action as necessary and legitimate for the attainment of these goals legitimation or justification.

Brock et al, however, deplore contemporary platforms of political communication, which exhaust their rhetorical aptitude to the simplification and personalization, as being deprived of a genuine ideological orientation. "They are devoid of historical content and offer little to predict how one group or the other will respond to changing circumstances. This lack of coherence, context, and predictability has a debilitating effect on political decision-making. [...]" $(2005,2)$; it leads to the betrayal of trust, since political actors often fail to deliver promises based on ephemeral issue-oriented sloganized statements, and to the unviability of broader coalitions among political factions that are necessary for the effective exercise of power; it assures short-term winning of votes rather than long-term secured majorities. Consequently, the remedy to this 'political gridlock', according to the authors, is the systematic re-grounding of political motives and frames on broader, coherent and historically enduring, vernacular philosophies, such as the liberal, conservative, radical and reactionary position in American politics (ibid).

By relating ideology to the effective access to, securing and exercise of power through language, Brock et al have offered a very clear and powerful statement of the constitutive role ideology plays in political pragmatism. However, as I wish to argue, their analysis suffers from an essentialist conception of 'proper political discourse' as rational, coherent and primarily verbalized, deeply rooted in the still influential in political science legacy of Enlightenment. According to this conception, the distracting, disorienting and irrational nature of visuals and emotions, which are now argued to dominate platforms of political communication, such as the political ads (see Qualter, 1991, Franklin, 2004), are excluded from the sphere of the, alleged, pure political thought. Such an 'exclusion', however, regrettably obfuscates the, always constitutive of the political, role of aesthetics, such as images, personality attributes, symbolisms and popular culture artefacts, in familiarizing the public with the, otherwise, abstract and distant institutional procedures of politics (see Pfeffer, 1981, March and Olsen, 1984, Cohen, 1974, Street, 1997, van Zoonen, 2004, Balmas 
and Sheafer, 2013) and of emotions as heuristic mechanisms of thought which can prioritize several political attitudes over others (see Damasio, 1994, Oatley and Jenkins, 1996, Berezin, 2002).

By this token, I do not want to imply that aestheticized politics necessarily serves substantive goals in any case. I rather want to stress that there is nothing, a priori, essentially denigrating, destructive or anti-rational (albeit it might be irrational or non-rational) in the visually articulated and emotionally motivated use of language, inasmuch as there is nothing essentially valuable, productive or pro-rational in the verbally articulated and 'reason'oriented use of language. Of course, the supporters of the idea of 'proper political discourse' are right in arguing that the trivializing and sensational aesthetic and emotional aspects of political discourse cannot articulate a coherent narrative grounded on political philosophy. The notion of coherence is highlighted here since it is considered to be a necessary condition for the effective exercise of power in terms of securing long term coalitions (Brock et al, 2005). This is, however, an assumption crucially predicated on a superficially consensual understanding of the effective exercise of political power (see Hall, 1982, Lukes, 2005). As several critiques have pointed out, and to which I shall now turn my attention, language cannot establish and serve political consensus since it is inextricably intertwined with the structural asymmetries, originated from class, gender, ethnicity, income level, inter-state competition, etc., that underlie its production and use in specific contexts.

\section{Ideology as the Discursive Dissimulation and Normalization of Asymmetries that secures Domination}

For the critical students, instead of the rational attainment of consensus, political language is oriented at constructing the consent of the subordinates in ways that the aforementioned asymmetries are concealed or normalized and, thereby, the dominant groups will continue to rule. As Gramsci has succinctly pointed out, for the hegemony of the dominant classes to be effectively sustained and reproduced, the interests of the latter should not be perceived by subordinates as being imposed on them but as converging the 'common sense' (1971), what Marx has also described as the universalization of interests of the ruling class (1970). From this point of view, dominant classes rule only in so far as they are capable of renewing the consent of the ruled. Stuart Hall, following Gramsci and Volosinov, has invaluably illustrated the inherently discursive nature of hegemony by stressing that social struggles around the construction of consent are conducted through several semiotic forms; the "'sign becomes an arena of class struggle" $(1982,77)$. Hall calls this semiotic struggle "the politics of signification" through which "different social interests or forces might conduct an ideological struggle to disarticulate a signifier from one, preferred or dominant meaning-system, and rearticulate it within another, different chain of connotations" $(1982,80)$.

This practice of disarticulation and re-articulation, which I shall call re-contextualization, is the par excellence mechanism of meaning-making in media platforms. Political ads, for example, which are the primary point of reference in this paper, extensively use signs which have been attached a symbolic meaning within a specific political culture (e.g. the red rose or the British bulldog in Labours' ads of 1997), re-articulating them, through the aesthetics of the representational techniques of the medium, with conventional patterns from popular culture (e.g. horror/thriller or comedy patterns) (see Scammell and Langer, 2006, McNair, 2007). Critical cultural studies do not see this mediated 'politainment' with a good eye not because it defiles the sanctity of rational political discourse as such but because it gives rise to a political culture in which citizens-consumers are learned to valorize the superficial, episodic and personal aspects of the political spectacle at the expense of the underlying 
structural problems and inequalities. Aestheticized political discourse prevents people from questioning the social order, in other words, and, thereby, it secures the hegemony of the latter (Hall, 1977, Curran, Douglas and Whannel, 1980, Edelman, 1988, Iyengar, 1991).

Arguably, the insight we get from the critical paradigm in the study of ideology, that pragmatism in contemporary political communication, experienced through the manageriallydriven use of the aesthetic features of mediated discourse, seeks to dissimulate and/or normalize the widely conflictual and asymmetric nature of the social so as to serve the hegemony of a specific dominant order, is invaluably helpful in challenging the naïve consensualism as underpinning of the effective exercise of power. The question, however, is if in a context of radical antagonism and conflict among the numerous and permeable networks of power, we can still talk, first, about the - even temporary - existence of a single, unified and solid 'social order', 'domination' or 'hegemony' and, second, about the orchestrated dissimulation or normalization of social asymmetries as the only, necessary, discursive means of exercising power (Mouffe, 1999, Lash, 2007, Castells, 2009). As Thompson has acutely put it "social theory can relinquish the need to find a conductor for the concert of social reproduction, not so much because this concert is performed without a conductor [...] but because social reproduction is not a concert than a cacophony of discordant and divergent notes" $(1984,62)$. In such a fragile network of inextricably interrelated, and sometimes, mutually exclusive interests and permeable relations of domination, the exercise of power cannot be confined to the dissimulative and unifying function of language; it needs to be widened including all the potential ways, e.g. uncovering and fragmentation, via which the multimodal semiotic patterns of electronic ads and of other platforms of political communication seek to sustain some relations of domination and challenge some others.

\section{Ideology as a Discursive Practice of Re-contextualization of Symbolisms}

The critiques against both political science and cultural studies approaches to the ideological potential of language, I have articulated so far, are, crucially, moving within the framework of post-structuralist theory of discourse and power (see Laclau and Mouffe, 1985) which, in its core principles, denies any essentialist, consensual and reductionist conception of political discourse and its role in contemporary political communication. Quite the contrary, political discourse is fundamentally characterized by 'radical contingency' which means that there is no fixed meaning immanent to specific set of ideas but only 'empty signifiers' that periodically acquire meaning in the process of articulation or re-contextualization (ibid). As Freeden points out, drawing on the insights of post-structuralism, the meaning-making process must be seen as ongoing and open-ended, the defining aspect of which is not coherence and stativity but indeterminacy and contestability (2003). This is not, however, a claim contrived to defend the political and ideological integrity of some postwar political discourses, such as the so-called 'Third Way', which have been repeatedly deplored as market-oriented, discursive constellations and hybrids driven by the need to find workable policies and re-boost the damaged electoral credibility of political parties (Heywood, 2003). It is rather an ontological condition of political discourse now and then; even of the prewar discursive formations which have been celebrated for their rigid, polemic and totalizing dogmatic nature, such as fascism. If in the case of 'Third Way', for example, someone can see how elements from neo-liberalism, social liberalism, communitarianism and social democracy are bound up together to rebrand left-of-center political parties, such as the British Labour Party, as modern, moderate and above all ready-to-govern parties (Giddens, 1998, Heywood, 2003, Fairclough, 2001, Lees-Marshment and Lilleker, 2001), in the case of fascism, s/he can, in the same sense, identify the effective articulation of old conservatism 
with counter-revolutionary ethos and militarism as a unified alliance of the Right (Hobsbawm, 1995).

In both cases, what is underway is a practice of re-contextualization of symbolisms from the past in such a way so as a specific institutional setting to reinforce its relational position in the broader political field. If, however, fascism achieved to reinforce the relational position of the German ethno-socialist party in an extreme and totalitarian hegemonic way this should not be taken as the par excellence way via which re-contextualization serves the exercise of power. It is the particular social and historical conditions in the interwar period (e.g. politicomilitary competition, the economic slump and the nature of Hitlerian rule) that allowed this phenomenon and it is again the social and historical conditions in 90s (e.g. growing international uncertainty and instability, legitimacy crisis of institutions, disaffection) that did not allow the 'Third Way' project to amount to a form of total ideological domination, although this project led the British Labour party to three consecutive electoral victories and a full rebound in its governmental path.

The association of re-contextualization, however, with the relational reinforcement and not the hegemony of an institutional setting does not mean that the power potential of recontextualization is exhausted at the level of electoral impact. The re-contextualization of symbolisms may be strategically planned by politicians, consultants, media-savvy persons, etc. as a weapon in the electoral fight but it also always, regardless of actors' specific intentions, carries with it the social asymmetries and interests that are interweaved with the institutional setting within which this practice is situated (Chouliaraki and Fairclough, 1999). The re-articulation of the 'British bulldog', for example, a traditional symbol of British nationalism normally used by the Conservative party, with humanitarian and philanthropic connotations in Labours' ads before the 1997 general election (see McNair, 2007), was surely contrived as a strategy to re-attract voters that had been disappointed by Labour's stances on national issues without, however, 'surprizing' them with a, rather alien for party history, hard-core nationalism. At the same time, this particular re-contextualisation of the symbolism of patriotism, seeks to legitimize international asymmetries deriving from the implied 'British superiority' on a new basis; superiority in 'philanthropic, humanist and universalist' rather than on ethnically essentialist terms. Consequently, re-contextualization must be conceived as discursive practice that always intersects with a multiple set of relations of domination by sustaining some of them and/or challenging some others at the benefit of the institutional setting within which it is situated.

Based on these remarks, I wish to argue that to study ideology is not to study the grand ideas and belief systems of the past as such but the socially and institutionally situated discursive practices though which symbolic fragments from these ideas and belief systems are recontextualized giving rise to new discursive formations. Moreover, to study ideology is not to study these discursive formations in terms of their role in the establishment of consensus or hegemonic order but the different ways via which they intersect with the numerable and permeable relations of domination. Consequently, to the extent that platforms of contemporary, managerially-driven and aesthetically-ridden, political communication can operate as discursive practices of re-contextualization of symbolisms which seek to reinforce the relational position of an institutional setting within the broader political field (by sustaining some and/or challenging some other relations of domination), we can talk about the potential of political communication to constitute the substratum for the construction of political ideology and of the potential of political ideology to constitute the means via which the objectives of pragmatism may be pursued in political communication. In what follows, I 
shall delineate an analytical framework through which political ads as practices of political communication can be studied in terms of this potential, that is, in terms of a) how their systematized features and conventional patterns of signification may facilitate the recontextualization of symbolisms and b) how re-contextualization and its discursive products intersect with relations of domination, thereby, enabling the institutional setting to make greater impact on the political field.

\section{Towards an Analytical Framework of Understanding the Ideological Potential of Televised Political Advertising}

The compositional structure of political ads, as well as of all other mediated forms of political communication, follows some conventional patterns of representation, which 'tell familiar stories with familiar characters in familiar situations" (Grant, in Scammell and Langer, 2006, 770), known as genres. In discourse analytic terms, genre is taken to effectively materialize, in the technologically inscribed multimodal forms of semiosis (pictorial, visual, verbal, etc.), patterns of social action and self-presentation that develop within specific institutional settings (see Fairclough, 2003, Chouliaraki, 2006). For instance, the "man-in-the-street or testimonial' genre by representing lay persons in the contexts of their everyday life, construes politics as a directly accessible and open-to-all activity (simplification or what Fairclough calls 'conversationalization' of politics [1995]) while the 'talking head' genre by highlighting the skills and charismatic personality of the leader construes politics as a strategic game that needs competent players (personalization) (see McNair, 2007). It is, therefore, through the analysis of genres that we can, analytically, get access to these patterns which exemplify the managerial and aestheticized nature of contemporary political communication, such as the personalist, the conversationalist, spectacularist, etc.; more particularly, to understand in what ways they serve the practice of re-contextualization of symbolisms (strategies of intertextuality) and how they seek to reinforce the relational position of the institutional setting through these ways (modes of social consequentiality of intertextuality).

Political ads are almost never confined to a single genre but they bring together and imbricate different genres and thereby, different patterns of self-presentation and social action (Scammell and Langer, 2006, McNair, 2007). This synthetic aspect of ads may be referred, in discourse analytic terms, as intertextuality; a concept borrowed by Kristeva (1986), whose inspiration, however, is indebted to the work of Mikhael Bakhtin. Intertextuality in its narrow sense is 'manifest' (Fairclough, 1992), that is, when specific phrases, images, sounds, etc. from other texts ('text' in the broad sense, as multimodal semiotic constructions) are explicitly quoted in the text under consideration. Here I am more interested, however, in the less manifest but more constitutive of texts form of intertextuality as the integration into the production of texts not only of directly attributable meanings but of conventionalized social constructions, symbols, cultural sedimentations, what Kristeva refers to as 'insertion of history into text" (1986, in Fairclough, 1992, 279) or what Fairclough calls 'interdiscursivity' (1992). Arguably, intertextuality can be treated as the analytical instantiation of re-contextualization which, as a fundamentally historicist concept, calls for our attention to the study of the past of specific institutional settings, and more particularly, to the identification in texts of the cultural-historical conventions that are embedded in the context under examination. Intertextual analysis can be, therefore, the key for spelling out the social and historical conditions of possibility of ideological construction in political ads.

\section{Strategies of Intertextuality/Interdiscursivity}

Strategies of intertextuality are conventional patterns of signification through which genres can re-contextualize symbolisms bringing, thereby, specific discourses into the text. Let me 
briefly refer here to some indicative strategies of intertextuality. Such a strategy could be what John Thompson (1990) calls narrativization, the recounting, through a storytelling pattern, of symbols from the past as values of a cherished tradition (see also Fairclough, 2003, Rose, 2007). One of the spots launched by the US Democratic Party before the 2008 presidential election, ('the country I love'), extensively used the strategy of narrativization, both verbally, through the voiceover of Barak Obama (e.g. 'I was raised by a single mum and my grandparents') and visually, through real pictures of him as baby in his mother's bosom, later as a student, young professional and a man engaging with commons (Museum of the Moving Image, 2012). On the one hand, this strategy is inextricably bounded here with a generic version of the talking head spot which by highlighting the various intimate aspects of the leader's personality and its potentially charismatic attributes exemplifies the highly individualized style of American political communication (Norris, 2004). On the other hand, however, the narrative of Obama's personal life in this spot recounts several symbols (referred as 'values') that have their own distinctive historical significance in the US context, such as the symbol of constitutional and rational-legal authority, that is enclosed in the word 'accountability' and the reigning symbol of patriotism, connoted in the phrase 'love of country' and in the picture that captures Mr. Obama's gesture of solidarity to an American serviceman (Museum of the Moving Image, 2012).

Another relevant strategy is that of displacement, via which the symbolic meaning (positive or negative) that is customarily attached to a specific object (term, image or a sound) is transferred to another symbol that is now related to that object (Thompson, 1990). In one of its electoral broadcasts for the 2010 general election, ('A new kind of government for Britain'), the British Conservative Party tried to summarize its renewed manifesto through the stories of three lay persons, a single-mother with two children, a homeless charity volunteer and a hydraulics business owner, obviously employing the so-called 'testimonial or man-in-the-street' genre. Albeit simplified, the representation, through this rubric, of politics as a quotidian practice is not necessarily simplistic. In the story of the single-mother, for instance, we can notice that a core symbol of conservatism, that of strong family, is visually and verbally recounted but not within its traditionalist patriarchal connotations; the notion of 'strength' is attached here some 'libertarian' signifieds, I would say, such as the signified of the independent, self-reliant, woman which can be derived from the images which represent a single working mother that have to act, daily, in several settings - in her home doing the domestics, in the playground spending time with her children and in her workplace being devoted to her job (BBC, 2010).

Several tropes, such as synecdoche, metonymy and metaphor may also serve the recontextualizing principle. Metaphor, for instance, which is widely used in advertising, is a trope that aims at familiarizing a group of people with an object, idea or situation that is alien to it, by referring to the latter in terms and ideas already familiar to the collective memory (Fiske, 1982, Thompson, 1990, Thwaites, Lloyd and Warwick, 1994). In the run-up to the general election of 2009, the Greek socialist party, PASOK, released a spot titled 'Go', which represents the party leader to head to the arena of a weightlifting stadium, probably to give a speech, being hailed and applauded by the gathered crowd (greekbox, 2009). This 'cinemaverite generic rubric' (see McNair, 2007) uses the metaphor of an awaited race (the leader as gladiator in the arena) to point to the forthcoming election or/and to the post-election period in which the 'winner' would have to fight against the economic crisis. Arguably, the metaphor of race and gladiator encourages a dramatic/spectacular style of representing politics but, the same time, it allows symbols of adaptation and austerity, such as struggle and hard work - tremendously unpopular and marginalized in, the dominated by the populist and 
carefree 'Discourse of Hope', Greek political culture (Voulgaris, 2008) - to re-enter the public debate. In contrast to previous electoral battles, in which the Discourse of Hope was recalled almost intact, as far as its populist and polarising elements are concerned (Vamvakas, 2006), in that election both these characteristics were substantially ameliorated in the favour of a new discursive formation which re-articulates hope in the context of struggle and adaptation.

Narrativization, displacement and tropes are by no means the only strategies of intertextuality and, therefore, this list should be seen rather as an indicative one and open to future enrichment and/or refinement by the empirical work.

\section{Modes of the Social Consequentiality of Intertextuality}

Re-contextualization is a socially consequential practice, in terms that it discoursaly organizes and orders other social practices (Chouliaraki and Fairclough, 1999). As it has been stressed in the previous section, this organizing and ordering capacity of re-contextualization, and of social practices in general, is not determined to secure a rationally attained political consensus or a dissimulative consent-based hegemony but it is not also arbitrary and unconditioned. Re-contextualization carries with it the multidimensional institutional interests and pursuits as well as the multivalent social asymmetries of the context with which it is situated (ibid). Re-contextualization, therefore, as a discursive practice may perform its ordering role by legitimizing a specific sort of social asymmetries (Thompson, 1990) and, potentially, de-legitimatizing others (see Eagleton, 1991). It may also works to dissimulate or mystify and reify or normalize specific pursuits and social asymmetries (Hall, 1982, Thompson, 1990, Chouliaraki and Fairclough, 1999) as well as to uncover and de-reify the opposing ones (see Terdiman, 1985). Finally, it may unify and/or fragment social groups (Thompson, 1990) with which political parties are affiliated.

Under specific circumstances, some of the strategies of intertextuality examined earlier may be mobilized to bring to the fore discourses that seek to intervene in the network of power in particular ways, thereby, being associated with particular modes of the social consequentiality of intertextuality - e.g. the strategy of narrativation may give rise to a discourse that is oriented at legitimizing social asymmetries (see Thompson, 1990). However, albeit inextricably intertwined, strategies of intertextuality and modes of social consequentiality of re-contextualization are by no means causally linked (ibid). It is a matter of critical interpretation of the discursive products of re-contextualization to establish links per se, based on the contextual conditions that underlie the production of particular ads, such as the electoral competition, the challenges the party faces and the pursuits and interests it prioritizes in respect with a specific electoral campaign.

The 'Discourse of social values', for instance, which is articulated in the spot by the US Democratic party, through the strategy of narrativization, is crucially related to several challenges Barack Obama faced during his presidential campaign. For instance, the middleof-the-road plan for government, which is considered to be the sine qua non for successful electioneering in the US (Zaller, 2001), was disputed by allegations about Obama's affiliation with the radical views of his pastor Jeramiah Wright (Dilanian, 2008) and about his early influence from Frank Marshal Davis who had been suspected of being member of the Soviet communist party (Harnden, 2008). The recounting of 'sacred' values from the history of the nation was necessary (especially as far as undecided but conservative-minded voters are concerned) for legitimizing Obama's positions on national (e.g. retreat of American troops from Iraq) and social (e.g. explicit and strong defense of gay rights) issues as deeply 
grounded on political moderation and as non-threatening for existing entitlements. The challenge for the British Conservative party in the run-up to the 2010 general election can be said to be almost the opposite. Tories did not need to emphasize their conservative inheritance but rather to ameliorate it so as to deal with the substantial empowerment of Liberal Democrats under the leadership of the quite popular Nick Clegg. The 'Discourse of strong family' by displacing the patriarchal signifieds of 'strength' with more liberal and libertarian ones crucially uncovers and the same time exorcize the existence of gender inequalities, seeking, primarily, to prevent disappointed Labour voters with strong liberal views from heading to the Lib Dems.

The amelioration of the populist and polarizing aspects of the Discourse of Hope through the metaphor of the race in PASOK's spot had also its own contextual explanation and intentionality. PASOK was aware of the dramatically deteriorated state of the Greek economy and, therefore, of the need to urgently employ measures to cope with it. At the same time, PASOK did not need to polarize the electorate since its traditional electoral basis appeared to have been already highly mobilized and it did not also need to resort to populist campaigning since according to all polls its victory was much more than certain (eklogika, 2011). Consequently, the 'Discourse of Hopeful Struggle' found a fertile ground to demystify the no longer sustainable unconditional hope (no adaptations, no efforts, no cuts, etc.) without, however, specifying the conditions under which hope may be responsibly reconceived. The general and abstract reference to 'hopeful struggle' can be said, therefore, to dissimulate potential sacrifices that specific social groups would be (as they were finally) required to do after the election. In this way, PASOK avoided broaching issues which might cause significant rupture to the block of social relations that would bring it back to power.

\section{Conclusion}

If I had to summarize the whole paper in one sentence this would be the following: By drawing analytical attention to genres of political communication, beyond monolithic essentialisms and reductionisms, we can get subtler insights into how aestheticized political discourse is engaged with the re-contextualization of symbolisms and the reinforcement of the relational position of a political party. In a nutshell, we can get a clearer idea about how political ideology is constructed in practices of political communication bearing distinct effects across contexts. As I tried to argue, ideology is constructed not necessarily on the basis of historically consolidated antinomies, expressed in 'grand philosophical' narratives, but on the basis of the harmonic integration of free-floating symbols from the past into the personalized, conversationalized and dramatized political communication of the present. Irrespective, therefore, of the temporal dimension of each research project, the study of the past in terms of the historicity of a specific context is a necessary ingredient in the understanding of the present, not in an abstract philosophical sense but from the angle of political pragmatism. If ideological construction as the re-contextualization of political symbolisms through aestheticized platforms of political communication, such as the political ads examined here, seeks to reinforce the relational position of a party by sustaining and/or challenging the relations of domination with which this party is interweaved, then political ideology is definitely a prerequisite of managing institutional uncertainty and instability and strengthening electability, not a derivative of them. Finally, if a quantitative analysis of political communication can be informative about the direct and linear effects of representational techniques and messages, a qualitative critical analysis, as the one presented in this paper, can be informative about indirect, underlying and more pervasive impacts of ads, that is, about the discursive means via which political power may be negotiated, contested, reaffirmed, broadly speaking, exercised. 


\section{References}

Ansolabehere, S., \& Iyengar , S. (1995). Going Negative. How Political Advertisements Shrink and Polarize the Electorate. New York: The Free Press.

Atkin, C. K., \& Heald, G. (1976). Effects of Political Advertising. Public Opinion Quarterly, 40(2), 216-228.

Balmas, M., \& Sheafer, T. (2013). Charismatic Leaders and Mediated Personalisation in the International Arena. Communication Research, $X X(\mathrm{X}), 1-25$.

BBC. (2010, April 12). Party Election Broadcasts - General Election 2010. Retrieved April 30, 2015, from BBC News: http://news.bbc.co.uk/1/hi/uk_politics/election_2010/parties_and_issues/8593869.stm

Beck, U. (1992). Risk Society. Towards a New Modernity. London: Sage.

Berezin, M. (2002). Secure States: Towards a Political Sociology of Emotion. In J. Barbalet, Emotions and Sociology. Oxford: Blackwell Publishing.

Blumler, J., \& Gurevitch, M. (1995). The Crisis of Public Communication. London: Routledge .

Brock, B. L., Huglen, M. E., Klumpp, J. F., \& Howell, S. (2005). Making Sense of Political Ideology: The Power of Language in Democracy. MaryLand: Rowman and Littlefield.

Castells, M. (2009). Communication Power. Oxford: Oxford University Press.

Chouliaraki, L. (2006). Towards an Analytics of Mediation. Critical Discourse Studies, 3(2), 153-178.

Chouliaraki, L., \& Fairclough, N. (1999). Discourse in Late Modernity. Rethinking Critical Discourse Analysis. Edinburgh: Edinburgh University Press.

Cohen, A. (1974). Two-Dimensional Man. An essay on the anthropology of power and symbolism in complex society. Berkeley and Los Angeles: University of California Press.

Curran, J., Douglas, A., \& Whannel, G. (1980). The political economy of the human-interest story. In A. Smith, Newspapers and Democracy. Cambridge: Mass: Massachusetts Institute of Technology .

Cwalina, W., Falkowski, A., \& Kaid, L. L. (2000). Role of Advertising in Forming the Image of Politicians: Comparative Analysis of Poland, France and Germany. Media Psychology, 2(2), 119-146.

Dahl, R. A. (1971). Polyarchy: Participation and Opposition. New Heaven: Yale University Press.

Dahlgren, P., \& Gurevitch, M. (2005). Political Communication in a Changin World. In J. Curran, \& M. Gurevitch, Mass Media and Society (4th ed., pp. 375-393). London: Arnold.

Damasio, A. (1994). Descartes' Error. New York: Quill.

Dilanian , K. (2008, March 18). Defenders say Wright has love, righteous anger for USA. Retrieved April 29, 2015, from USA Today: http://usatoday30.usatoday.com/news/politics/election2008/2008-03-18obamawright_N.htm

Eagleton, T. (1991). Ideology. An Introduction. London: Verso.

Edelman, M. (1988). Constructing the Political Spectacle. Chicago: Chicago University Press.

Eklogika. (2011, October 13). Dimoskopiseis [Opinion Polls]. Retrieved from Eklogika.gr: http://www.eklogika.gr/gallup

Fairclough, N. (1992). Intertextuality in Critical Discourse Analysis. Linguistics and Education, 4, 269-293. 
Fairclough, N. (1995). Media Discourse. Cambridge : Polity.

Fairclough, N. (2001). The Discourse of New Labour: Critical Discourse Analysis. In M. Wetherell, S. Taylor, \& S. J. Yates, Discourse as Data. A Guide for Analysis (pp. 229-266). London: Sage.

Fairclough, N. (2003). Analysing Discourse: Textual Analysis for Social Research. London: Routledge.

Fiske, J. (1982). Introduction to Communication Studies. London: Routledge.

Foley, M. (1994). Ideas that shapes politics. Manchester: Manchester University Press.

Franklin, B. (2004). Packaging Politics: Political Communications in Britain's Media Democracy (2nd ed.). London: Arnold.

Freeden, M. (2003). Ideology. A Very Short Introduction. New York: Oxford University Press.

Giddens, A. (1990). The Consequences of Modernity. Cambridge: Polity.

Giddens, A. (1998). The Third Way. The Renewal of Social Democracy. Cambridge: Polity Press.

Gramsci, A. (1971). Selection from the Prison Notebooks. London: Lawrence \& Wishart.

greekbox. (2009, September 30). Papandreou Pame! Prothipourgiko spot [Papandreou Go! Prime-ministerial spot]. Retrieved April 29, 2015, from YouTube: https://www.youtube.com/watch?v=5E7jpU0xWuk

Hall, S. (1977). Culture, the Media and the 'Ideological effect'. In J. Curran, M. Gurevitch, \& J. Woollacott, Mass Communication and Society (pp. 315-348). London: Arnold.

Hall, S. (1982). The rediscovery of 'ideology': the return of the repressed in the media. In M. Gurevitch, T. Bennett, J. Curran, \& J. Woollacott, Culture, Society and the Media (pp. 56-90). London: Methuen.

Halliday, M. A. (1995). Introduction to Functional Grammar. London: Arnold.

Hallin, D. C., \& Mancini, P. (2004). Comparing Media Systems. Three Models of Media and Politics. New York: Cambridge University Press.

Hamilton, M. B. (1987). The Elements of the Concept of Ideology. Political Studies, XXXV, $18-38$.

Harnden, T. (2008, August 22). Frank Marshall Davis, alleged Communist, was early influence on Barack Obama. Retrieved April 29, 2015, from The Telegraph: http://www.telegraph.co.uk/news/worldnews/barackobama/2601914/Frank-MarshallDavis-alleged-Communist-was-early-influence-on-Barack-Obama.html

Heywood, A. (2003). Political Ideologies: An Introduction (3rd ed.). New Yor: Palgrave Macmillan.

Hobsbawm, E. (1995). Age of Extremes: The Short Twentieth Century 1914-1991. London: Abacus.

Hoffman , J., \& Graham, P. (2006). Introduction to Political Ideologies . London: Pearson Longman.

Iyengar, S. (1991). Is Anyone Responsible? How Television Frames Political Issues. Chicago: University of Chicago Press.

Kahn, K. F., \& Geer, J. C. (1994). Creating Impressions: An experimental investigation of political advertising on television. Political Behavior, 16(1), 93-116.

Kaid, L. L. (2002). Political advertising and information seeking: Comparing exposure via traditional and Internet channels. Journal of Advertising, 31(1), 27-36.

Kaid, L. L., \& Sanders, K. R. (1978). Political television commercials : An experimental study of the type and length. Communication Research, 5(1), 57-90.

Kaid, L. L., Chanslor, M., \& Hovind, M. (1992). The influence of program and commercial type on political advertising effectiveness. Journal of Broadcasting and Electronic Media, 36(3), 303-320. 
Kaid, L. L., Fernandes, J., \& Painter, J. (2011). Effects of Political Advertising in the 2008 Presidential Campaign. American Behavioral Scientist, 55(4), 437-456.

Kaid, L. L., Postelnicu, M., Landreville, K., Yun, H. J., \& LeGrange, A. G. (2007). The effects of political advertising on young voters. American Behavioral Scientist, 50(9), $1137-1151$.

Knight, K. (2006). Transformations of the Concept of Ideology in the twentieth. The American Political Science Review, 100(4), 619-626.

Kristeva, J. (1986). Word, dialogue and novel. In T. Moi, The Kristeva Reader (pp. 33-61). Oxford: Basil Blackwell.

Laclau, E., \& Mouffe, S. (1985). Hegemony and Social Strategy: Towards a Radical Democratic Politics. London: Verso.

Lash, S. (2007). Power after Hegemony: Cultural Studies in Mutation. Theory, Culture \& Society, 24(3), 55-78.

Lees-Marshment, J., \& Lilleker, D. (2001). Political Marketing and Traditional Values: 'Old Labour for 'New Times'? Contemporary Politics, 7(3), 205-216.

Lewins, F. (1989). Recasting the Concept of Ideology: A Content Approach. The British Journal of Sociology, 40(4), 678-693.

Luhmann, N. (1975). Macht [Power]. Stuttgart : Enke Verlag.

Lukes, S. (2005). Power: A Radical View (3rd ed.). London: Macmillan.

March, J. G., \& Olsen, J. P. (1984). The New Institutionalism: Organizational Factors in Political Life. The American Political Science Review, 78(3), 734-749.

Marx, K., \& Engels, F. (1970). The German Ideology. London: Lawrence and Wishart.

McNair, B. (2007). An Introduction to Political Communication (4th ed.). Abingdon: Routledge.

Mouffe, C. (1999). Deliberative Democracy or Agonistic Pluralism. Social Research, 66(3), 746-758.

Mullins, W. A. (1972). On the Concept of Ideology in Political Science. The American Political Science Review, 66(2), 498-510.

Museum of the Moving Image. (2012). Presidential Campaign Commercials 1952-2012. Retrieved April 30, 2015, from The Living Room Candidate.

Norris, P. (2004). Electoral Engineering: Voting Rules and Political Behavior. New York: Cambridge University Press.

Oatley, K., Keltner, D., \& Jenkins, J. M. (2006). Understanding Emotions (2nd ed.). Malden: Blackwell Publishing.

Pfeffer, J. (1981). Power in Organizations . Cambridge: Ballinger Publishing Company.

Qualter, T. (1991). Advertising and Democracy in the Mass Age. Basingstoke : Macmillan.

Rose, G. (2007). Visual Methodologies (2nd ed.). London: Sage.

Roucek, J. S. (1944). A History of the Concept of Ideology. Journal of the History of Ideas, $5(4), 479-488$.

Scammell, M., \& Langer, A. I. (2006). Political Advertising: Why is it so boring? Media, Culture and Society, 28(5), 763-784.

Seliger, M. (1976). Ideology and Politics. London: Allen and Unwin.

Street, J. (1997). Politics and Popular Culture. Cambridge: Polity Press.

Swanson, D., \& Mancini, P. (1996). Politics, Media and Modern Democracy: An International Study of Innovations in Electoral Campaigning and their Consequences. Westport, CT/London: Praeger.

Terdiman, R. (1985). Discourse/counter-discourse: The theory and practice of symbolic resistance in nineteenth-century France. New York: Cornell University Press.

Thompson, J. B. (1984). Studies in the Theory of Ideology. Cambridge: Polity. 
Thompson, J. B. (1990). Ideology and Modern Culture. Social Theory in the era of Mass Communication. Cambridge: Polity.

Thwaites, T., Lloyd, D., \& Warwick, M. (1994). Tools for Cultural Studies: An Introduction. South Melbourne: Macmillan.

Vamvakas, V. (2006). Elections and Communication in Metapolitefsi. Athens : Savvalas.

van Zoonen, E. (2004). Imagining the Fan Democracy. European Journal of Communication, 19(1), 39-52.

Voulgaris, Y. (2008). Greece in Metapolitefsi 1974-1990: Stable Democracy marked by postwar history (4th ed.). Athens: Themelio.

Zaller, J. (2001). Monica Lewinski and the Mainsprings of American Politics. In W. Bennett, \& M. Entman, Mediated Politics: Communication in the Future of Democracy. Cambridge: Cambridge University Press. 